In cooperation with the U.S. Army Corps of Engineers, Jacksonville, Florida

\title{
An Assessment of the Potential Effects of Aquifer Storage and Recovery on Mercury Cycling in South Florida
}
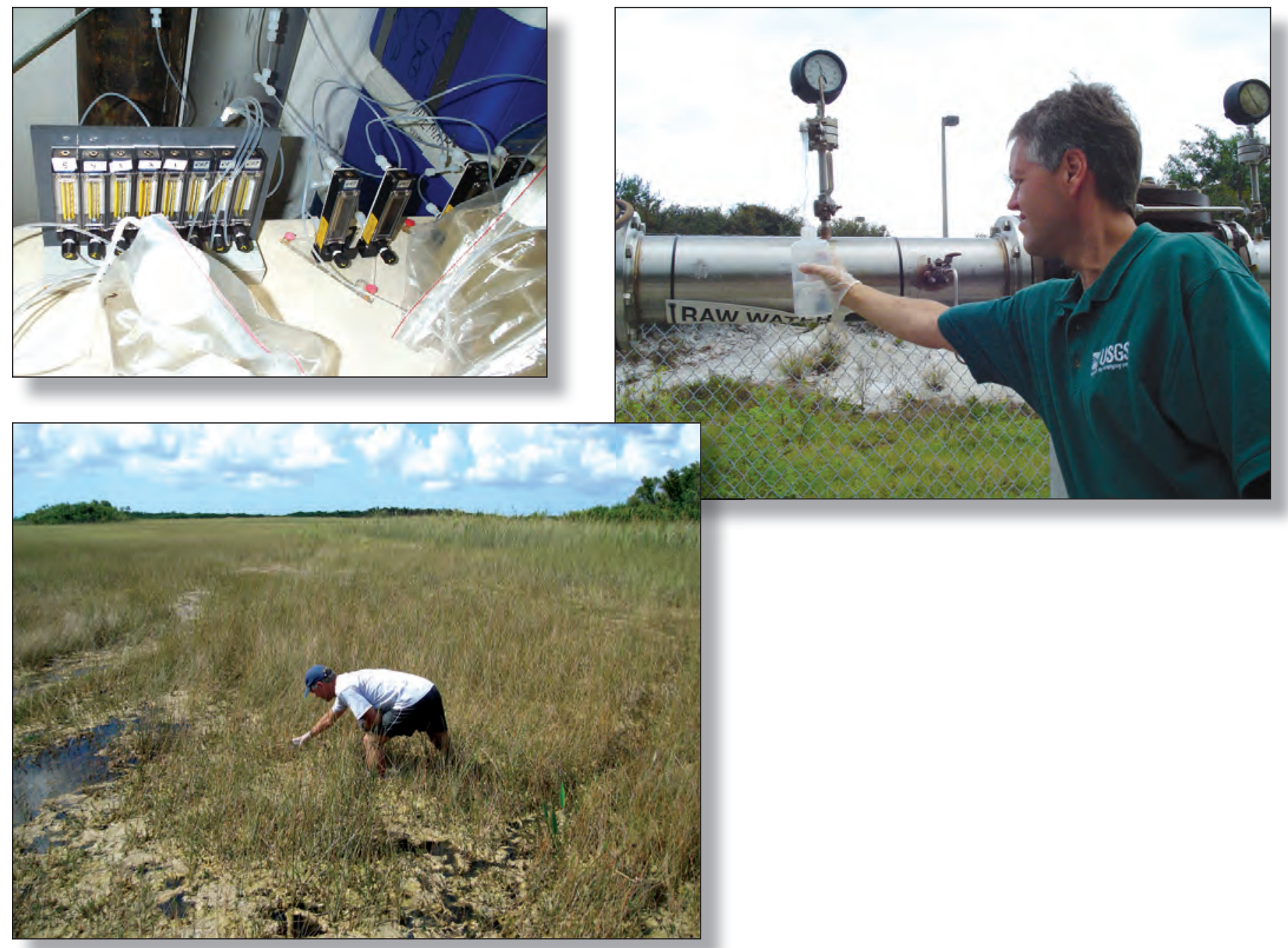

Scientific Investigations Report 2007-5240 



\section{An Assessment of the Potential Effects of Aquifer Storage and Recovery on Mercury Cycling in South Florida}

By David P. Krabbenhoft, George R. Aiken, and Mary P. Anderson

In cooperation with the U.S. Army Corps of Engineers, Jacksonville, Florida

Scientific Investigations Report 2007-5240 


\section{U.S. Department of the Interior DIRK KEMPTHORNE, Secretary}

\section{U.S. Geological Survey \\ Mark D. Myers, Director}

\section{U.S. Geological Survey, Reston, Virginia: 2007}

For product and ordering information:

World Wide Web: http://www.usgs.gov/pubprod

Telephone: 1-888-ASK-USGS

For more information on the USGS - the Federal source for science about the Earth, its natural and living resources, natural hazards, and the environment:

World Wide Web: http://www.usgs.gov

Telephone: 1-888-ASK-USGS

Any use of trade, product, or firm names is for descriptive purposes only and does not imply endorsement by the U.S. Government.

Although this report is in the public domain, permission must be secured from the individual copyright owners to reproduce any copyrighted materials contained within this report.

Suggested citation:

Krabbenhoft, D.P., Aiken, G.R., and Anderson, M.P., 2007, An assessment of the potential effects of aquifer storage and recovery on mercury cycling in South Florida: U.S. Geological Survey Scientific Investigations Report 2007-5240, $20 \mathrm{p}$.

Cover photographs:

Upper left: experimental setup used for the project;

Upper right: sampling an ASR well from a sampling tap;

Lower left: sampling in Everglades National Park. 


\section{Contents}

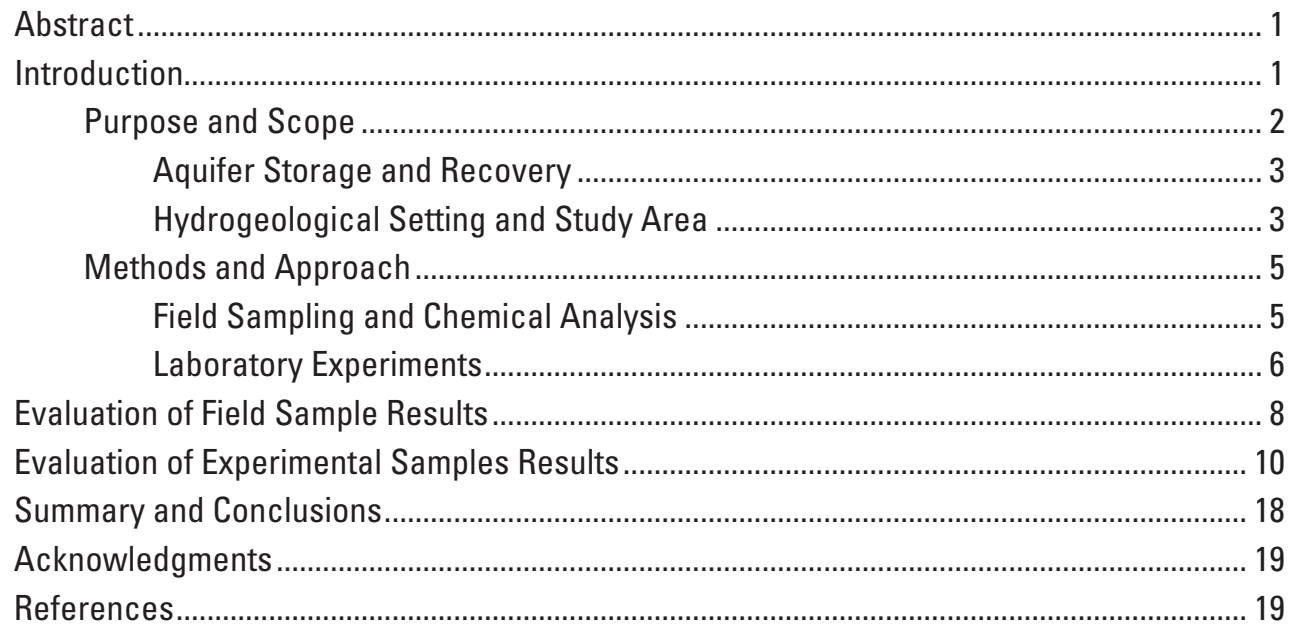

\section{Figures}

1. Map showing location of the study area in southeastern Florida............................. 4

2. Diagram showing laboratory incubation experiment apparatus................................ 7

3. Bar chart showing total mercury and methylmercury concentrations for the municipal water-supply wells sampled for this study......................................... 9

4-7. Graphs showing:

4. Results from experiments $A 1$ and $A 2$, replicate aerobic incubations containing surface water and crushed rock.

5. Results from experiments AN1 and AN2, replicate anaerobic incubations containing surface water and crushed rock..... 15

6. Results from experiments $A C$ and ANC, aerobic and anaerobic incubations, respectively, containing only filtered surface water...

7. Dissolved organic carbon and specific ultraviolet absorbance results from the aerobic experiments $A 1$ and $A 2$, and anaerobic experiments AN1 and AN2, which both contain filtered surface water and crushed rock

\section{Tables}

1. Location, date, aquifer, and depth of the sampled municipal wells in southeastern Florida

2. Results of specific chemical analyses of municipal wells ....................................... 10

3. Results of specific chemical analyses of major cations and anions from municipal wells

4. Results of specific chemical analyses of samples collected from laboratory incubation experiments 


\title{
Conversion Factors
}

\begin{tabular}{lll}
\hline \multicolumn{1}{c}{ Multiply } & \multicolumn{1}{c}{ By } & \multicolumn{1}{c}{ To obtain } \\
\hline inch (in.) & 2.54 & centimeter \\
foot (ft) & 0.3048 & meter \\
gallon per day (gal/d) & 0.003785 & cubic meter per day \\
liter (L) & 1.057 & quart \\
kilogram (kg) & 2.2046 & pound \\
Celsius $\left({ }^{\circ} \mathrm{C}\right)$ & $1.8 \times\left({ }^{\circ} \mathrm{C}\right)+32$ & Fahrenheit \\
\hline
\end{tabular}

\section{Additional Abbreviations}

\author{
ASR Aquifer Storage and Recovery \\ CERP Comprehensive Everglades Restoration Plan \\ CVAFS Cold vaporatomic fluorescence spectroscopy \\ $\mathrm{Hg}$ mercury \\ ${ }^{201} \mathrm{Hg}$ and $\mathrm{Me}^{199}$ isotope tracers \\ $\mathrm{MeHg}$ methylmercury \\ $\mathrm{mg} / \mathrm{L} \quad$ milligrams per liter \\ $\mathrm{mL} \quad$ milliliter \\ $\mathrm{ng} / \mathrm{L} \quad$ nanograms per liter \\ PETG polyethylene terephthalate $\mathrm{G}$ copolymer \\ SUVA specific ultraviolet absorbance \\ $\mathrm{SnCl}_{2}$ stannous chloride \\ TOC total organic carbon \\ USGS U.S. Geological Survey
}




\title{
An Assessment of the Potential Effects of Aquifer Storage and Recovery on Mercury Cycling in South Florida
}

\author{
By David P. Krabbenhoft, George R. Aiken, and Mary P. Anderson
}

\section{Abstract}

Mercury contamination in the environment is a global concern, especially in areas with abundant wetlands, such as south Florida. As the causal factors of this concern improve, scientists find that many factors that do not necessarily affect mercury concentrations, such as flooding and drying cycles, or changes to carbon and sulfate loading, can profoundly affect net mercury toxicity. Especially important are ecological factors that alter the conversion of mercury to methylmercury, which is the most bioaccumulative and toxic form of mercury in the environment. Resource managers, therefore, need to be aware of possible deleterious affects to mercury toxicity that could result from land and water management decisions. Several aspects of the Comprehensive Everglades Restoration Plan (CERP), including the planned Aquifer Storage and Recovery (ASR) program, have the potential to affect the abundance of methylmercury. In response to these concerns, the U.S. Geological Survey and U.S. Army Corps of Engineers collaborated on a study to evaluate how the proposed ASR program may affect mercury cycling and toxicity.

This project was conducted as an initial assessment of the possible effects of the CERP ASR program on mercury in the south Florida environment. A twofold approach was employed: field sampling and controlled laboratory benchmark experiments. The field sampling survey collected ground-water samples from the Floridan and surficial aquifer systems for the ASR program to determine existing levels of mercury and methylmercury. Laboratory experiments, on the other hand, were designed to determine how the injected surface water would interact with the aquifer during storage periods. Overall, very low levels of mercury and methylmercury (mean values of 0.41 and 0.07 nanograms per liter, respectively) were observed in ground- water samples collected from the Floridan and surficial aquifer systems. These results indicate that "recovered water" from the CERP ASR program would not represent a significant additional direct load of mercury and methylmercury to ASR "receiving waters." Net production of methylmercury, however, can result from additions of sulfate or natural organic carbon. Thus, because the Upper Floridan aquifer generally has elevated concentrations of sulfate (relative to ambient Everglades conditions) and surface waters near Lake Okeechobee (the assumed target for ASR receiving waters) are elevated in organic carbon and sulfate, at least some potential for increased methylmercury production might arise from the release of recovered ASR water to locations in or near the Everglades.

\section{Introduction}

The ecological restoration of the Everglades and the South Florida ecosystem is a challenging and significant environmental initiative. The Comprehensive Everglades Restoration Plan (CERP, 2002, http://www. evergladesplan.org), which was authorized by Congress in the Water Resources Development Act of 2000, provides a framework for restoring this ecosystem, and calls for improvements to water quality and overall health of the Everglades, enhancement of water supply for municipal and agricultural use, and maintenance of flood protection. Succinctly put, this plan calls for optimizing water supply, water use, and water quality in a way that is harmonious with the needs of a restored ecosystem and a rapidly growing population in southeast Florida. The overall strategy of all ASR programs is to optimize water availability and use of water supplies. Surface water is stored during wet months by injecting it into subsurface aquifers (in this case the Upper Floridan aquifer). During dry months, the 
injected water is recovered to help meet peak water-use demands. If implemented as envisioned, the ASR program for south Florida could include more than 300 ASR wells with a combined injection capacity of up to 1.7 billion gal/d and would require more than 30 years to complete (National Research Council of the National Academies, 2002).

Concerns over possible deleterious environmental effects from the south Florida ASR program prompted a review by the National Research Council Committee on Restoration of the Greater Everglades Ecosystem (National Research Council of the National Academies, 2002), which identified several key issues related to ASR that warranted further evaluation. One of the concerns was whether implementation of the ASR program might result in in situ mercury $(\mathrm{Hg})$ methylation within the Floridan aquifer system, and (or) exacerbated $\mathrm{Hg}$ methylation in the Everglades from the release of recovered water to the ecosystem (National Research Council of the National Academies, 2002; Wanless, 2004). In response to these concerns, the U.S. Geological Survey (USGS) and U.S. Army Corps of Engineers collaborated on a study to evaluate how the proposed ASR program may affect $\mathrm{Hg}$ cycling and toxicity.

Mercury methylation is the process that results in the conversion of inorganic $\mathrm{Hg}$ to methylmercury ( $\mathrm{MeHg}$ ), the most bioaccumulative and toxic form of $\mathrm{Hg}$. $\mathrm{MeHg}$ makes up nearly all of the $\mathrm{Hg}$ at the top of food webs where toxicological impacts are of concern, and factors controlling its genesis and transport are a focus of much $\mathrm{Hg}$ research. Concerns over elevated levels of $\mathrm{MeHg}$ in biota of the Everglades have been researched extensively, and the important causal factors are inputs of $\mathrm{Hg}$ from atmospheric deposition, variations in water quality (specifically, sulfate and dissolved organic carbon) related to runoff from the Everglades Agricultural Area, and hydroperiod maintenance (Krabbenhoft, 1996; Cleckner and others, 1998; Gilmour and others, 1998; Hurley and others, 1998; Krabbenhoft and others, 1998, Ravichandran and others, 1998; Bates and others, 2002). Although these studies have sufficiently linked the combined influences of land-use practices and atmospheric $\mathrm{Hg}$ inputs to the Everglades, and provided a basis for understanding and predicting possible impacts of various Everglades restoration activities on $\mathrm{Hg}$ toxicity, no specific information was available at the time of this study on the possible effects an ASR system in south Florida might have on $\mathrm{Hg}$ cycling and toxicity.

\section{Purpose and Scope}

The purpose of this study was to provide a scientific basis for evaluating whether concerns stated by the National Research Council (National Research Council of the National Academies, 2002) over possible exacerbation of $\mathrm{Hg}$ contamination of fish and wildlife in the Everglades due to implementation of the ASR program are warranted. At the initiation of this study, no reliable information existed on $\mathrm{Hg}$ or $\mathrm{MeHg}$ concentrations in south Florida aquifers, and there were no known studies that demonstrated whether ASR operations may trigger $\mathrm{MeHg}$ production. In response to this scientific information need, this study was designed and executed to help inform natural resource managers and planners in south Florida on the potential implications of the proposed ASR program on $\mathrm{Hg}$ cycling and toxicity.

For the past 15 to 20 years, researchers have revealed many of the underlying details regarding global $\mathrm{Hg}$ contamination, including sources, cycling, fate, and toxicological significance (Wiener and others, 2003). Relatively little research, however, has been conducted on $\mathrm{Hg}$ in ground-water systems, and no known studies have been conducted on $\mathrm{MeHg}$ formation in deep subsurface environments. Likewise, there are no known published studies that have evaluated possible interactions between operation of an ASR system and possible $\mathrm{MeHg}$ formation during storage periods, or the subsequent release of this potent neurotoxin to receiving waters during recovery. In addition, recent studies in the Everglades and elsewhere (Jeremiason and others, 2006; Orihel and others, 2006; Evers and others, 2007) have shown that additions of $\mathrm{Hg}$, sulfate, or organic carbon to wetlands can stimulate $\mathrm{MeHg}$ production. Thus, for the south Florida ASR program, net gains in $\mathrm{MeHg}$ abundance in the Everglades could result if appreciable $\mathrm{MeHg}$ production occurs in the aquifer during storage periods, or if the release of recovered water results in net increases in $\mathrm{MeHg}$ production. With these concerns in mind, the four goals of this study were to: (1) determine background ground-water concentrations of $\mathrm{Hg}, \mathrm{MeHg}$, and other relevant ancillary chemical constituents in the Upper Floridan aquifer and surficial aquifers; (2) determine whether there are any spatial trends in $\mathrm{Hg}$ and $\mathrm{MeHg}$ concentrations in the aquifers; (3) determine whether net $\mathrm{MeHg}$ formation could occur during ASR storage periods; and (4) determine whether net changes in $\mathrm{Hg}, \mathrm{MeHg}$, sulfate, and organic carbon could occur during storage 
periods. To achieve these goals, a multifaceted approach was employed that included field sampling and controlled laboratory experiments. Field sampling activities were designed to achieve the first two goals; controlled laboratory experiments were used to address the last two goals.

\section{Aquifer Storage and Recovery}

The following is a brief explanation of ASR; more detailed descriptions can be found in Pyne (1995) and National Research Council of the National Academies (2002). In the simplest terms, ASR is "the storage of water in a suitable aquifer through a well during times when water is available, and recovery of the water from the same well during times when it is needed" (Pyne, 1995). Water is typically stored in confined aquifers, such as the Upper Floridan aquifer, and observation wells are used to monitor hydrostatic pressure, water quality, and the movement of the stored water. The target storage volume is the volume of water that is anticipated to be needed for the recovery period, plus the volume of water in the buffer zone. The buffer zone separates the stored water from the native ground water and consists of a mixture of the two water types. ASR storage times are typically several months, but can range from a single day to several years. High recovery efficiency of the stored water is an important goal for successful ASR programs. In areas of high evaporation, such as Florida, recovery efficiency can be less than 100 percent and still be of net benefit to overall water management. One of the greatest concerns of an ASR program is unintended changes to water quality in the receiving aquifer due to the storage water having greatly different geochemical composition (most notably oxidation reduction potential, nutrients, and salinity). The ASR systems in southern Florida will generally store relatively fresh surface water in an aquifer containing brackish to saline water. The limiting salinity level is $250 \mathrm{mg} / \mathrm{L}$ chloride, or slightly higher if the recovered water is mixed with potable water at a water-treatment plant (Reese, 2002).

\section{Hydrogeological Setting and Study Area}

The study area for this project includes all or parts of Broward, Palm Beach, Martin, and St. Lucie Counties in southeastern Florida (fig. 1). A brief, general description of the hydrogeological setting is provided here; however, the reader is referred to Miller (1990), Reese and Memberg (2000), and Reese (2004) for detailed descriptions of the hydrogeology, lithology, and geochemical conditions in south Florida. The hydrostratigraphy of south Florida is made up of four units: the surficial aquifer system, Biscayne aquifer, intermediate aquifer, and Floridan aquifer system (Miller, 1990). The surficial aquifer system includes all unconfined aquifers that are present near the land surface (Miller, 1990), and is present everywhere in the study area except the southeastern corner, where the Biscayne aquifer is present as the surficial aquifer. Consisting mostly of quartz sand, silts, clay, shell beds, coquina, calcareous sandstone, and sandy, shelly limestone, the surficial aquifer system ranges in thickness from 50 to more than $300 \mathrm{ft}$ (Reese and Memberg, 2000). The Biscayne aquifer consists of highly permeable limestone and less permeable sandstone and sand. Miller (1990) indicates that the Biscayne aquifer grades to the north and west into sandy deposits that are part of the surficial aquifer system. In this report, these two shallow aquifers-the surficial aquifer system and the Biscayne aquifer-are generally referred to as the "surficial aquifers."

Underlying the Biscayne and surficial aquifer system is the intermediate confining unit, which is underlain by the Floridan aquifer system. The intermediate aquifer, present in southwestern Florida, grades eastward in southeastern Florida to become the intermediate confining unit. This unit provides good confinement for the Floridan aquifer system, and ranges in thickness from $250 \mathrm{ft}$ in Martin County to $750 \mathrm{ft}$ in Palm Beach County (Reese, 2004). The Floridan aquifer system is comprised of the Upper Floridan aquifer, the middle confining unit, and the Lower Floridan aquifer, which is underlain by the sub-Floridan confining unit. The principal focus of this study is the Upper Floridan aquifer, which is the target injection zone for the CERP ASR program. In southeastern Florida, the Upper Floridan consists of a band of permeable carbonate rock 500 to $600 \mathrm{ft}$ thick (Reese and Memberg, 2000). 

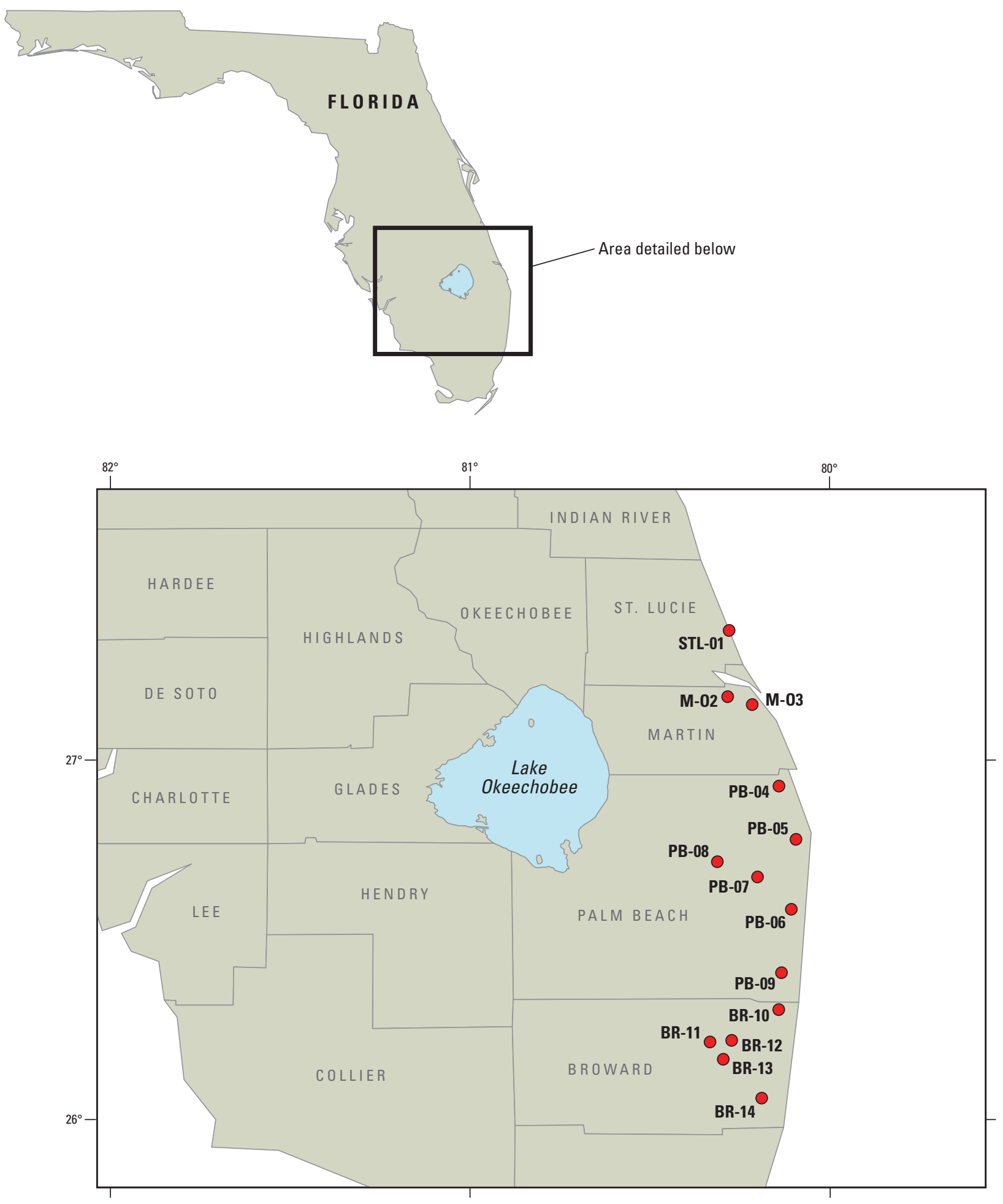

Figure 1. Location of the study area in southeastern Florida. Samples were collected at municipal water utilities (red circles) in Broward, Palm Beach, Martin, and St. Lucie Counties (modified from Reese, 2002). 


\section{Methods and Approach}

This study used a combined approach of field sampling and laboratory experiments to achieve the four goals of this project. Sampling ground water from 24 municipal water utilities provided information relevant to the first two goals (ambient concentrations of $\mathrm{Hg}$ and $\mathrm{MeHg}$ ). Laboratory experiments lasting 16 weeks were designed to address the last two goals (potential for $\mathrm{MeHg}$ formation during ASR operation and possible changes during storage periods). Combined, these efforts yielded complimentary data to provide an improved understanding of the potential linkages between ASR and $\mathrm{Hg}$ cycling and toxicity in south Florida.

\section{Field Sampling and Chemical Analysis}

Water samples were collected from 24 municipal water utilities in Broward, Palm Beach, Martin, and St. Lucie Counties in southeastern Florida (fig. 1; table 1) to determine background concentrations of total $\mathrm{Hg}$ and $\mathrm{MeHg}$, and general geochemical conditions of ground water within the surficial and Upper Floridan aquifers. Well depths ranged from 60 to $1,800 \mathrm{ft}$. The sampling sites were selected to provide a geographic representation of ground-water quality along the southeastern coast of Florida and a portion of the general area for the proposed ASR project. Permission to collect water samples was received from representatives of each municipal water facility.

Table 1. Location, date, aquifer, and depth of the sampled municipal wells in southeastern Florida.

[ID, identification number; NA, not available]

\begin{tabular}{|c|c|c|c|c|c|c|}
\hline County & Date sampled & Water utility name & $\begin{array}{c}\text { Map ID } \\
\text { (see fig. 1) }\end{array}$ & Aquifer & Utility well ID & $\begin{array}{l}\text { Well depth } \\
\text { (feet) }\end{array}$ \\
\hline Broward & $11 / 20 / 2003$ & City of N. Lauderdale & BR-12 & Biscayne & 2 & 125 \\
\hline Broward & $11 / 20 / 2003$ & City of Deerfield Bch & BR-10 & Biscayne & 19 & 108 \\
\hline Broward & $11 / 20 / 2003$ & Tamarac & BR-11 & Surficial & 1 & 60 \\
\hline Broward & $11 / 20 / 2003$ & City of Ft. Lauderdale & BR-14 & Biscayne & 37 & 115 \\
\hline Broward & $11 / 20 / 2003$ & City of Lauderhill & BR-13 & Surficial & 5 & 150 \\
\hline Palm Beach & $11 / 19 / 2003$ & Village of Tequesta & PB-04 & Floridan & 2 & 1,800 \\
\hline Palm Beach & $11 / 19 / 2003$ & Village of Tequesta & PB-04 & Surficial & 19 & 70 \\
\hline Palm Beach & $11 / 18 / 2003$ & City of Boca Raton & PB-09 & Biscayne & BR1 & NA \\
\hline Palm Beach & $11 / 18 / 2003$ & Village of Palm Springs & PB-07 & Surficial & 17 & 200 \\
\hline Palm Beach & $11 / 18 / 2003$ & Village of Palm Springs & PB-07 & Surficial & 12 & NA \\
\hline Palm Beach & $11 / 17 / 2003$ & Village of Wellington & PB-08 & Surficial & 24 & 180 \\
\hline Palm Beach & $11 / 17 / 2003$ & Village of Wellington & PB-08 & Surficial & 22 & 160 \\
\hline Palm Beach & $11 / 17 / 2003$ & Village of Wellington & PB-08 & Surficial & 19 & NA \\
\hline Palm Beach & $11 / 18 / 2003$ & West Palm Beach & PB-05 & Surficial & 2 & 150 \\
\hline Palm Beach & $11 / 18 / 2003$ & West Palm Beach & PB-05 & Floridan & ASR & 1,400 \\
\hline Palm Beach & $11 / 18 / 2003$ & Boynton Beach & PB-06 & Biscayne & $7 \mathrm{~W}$ & 161 \\
\hline Palm Beach & $11 / 18 / 2003$ & Boynton Beach & PB-06 & Biscayne & $15 \mathrm{E}$ & 233 \\
\hline Palm Beach & $11 / 18 / 2003$ & Boynton Beach & PB-06 & Biscayne & $6 \mathrm{E}$ & 76 \\
\hline Martin & $11 / 19 / 2003$ & City of Stuart & M-02 & Surficial & 3 & 130 \\
\hline Martin & $11 / 19 / 2003$ & Sailfish Point & M-03 & Floridan & 2 & 1,000 \\
\hline St. Lucie & $11 / 19 / 2003$ & Fort Pierce & STL-01 & Floridan & F-8 & 1,250 \\
\hline St. Lucie & $11 / 19 / 2003$ & Fort Pierce & STL-01 & Floridan & F-4 & 1,000 \\
\hline St. Lucie & $11 / 19 / 2003$ & Fort Pierce & STL-01 & Surficial & N7 & 80 \\
\hline St. Lucie & $11 / 19 / 2003$ & Fort Pierce & STL-01 & Surficial & $16 \mathrm{~S}$ & 100 \\
\hline
\end{tabular}


Samples were collected from wells that were in most cases (all but two) already producing upon arriving onsite, or were turned on and allowed to run for at least 15 minutes prior to sampling. Samples were collected from "sampling taps," which are small faucets affixed to the main production line for each well, and are upstream from any onsite treatment systems (for example, reverse osmosis).

Five individual water samples were collected sequentially from each well and subsequently analyzed for the following list of parameters: $\mathrm{pH}$ and conductivity; total $\mathrm{Hg}$ and $\mathrm{MeHg}$; total organic carbon; major cations; and major anions. All samples were collected after rinsing the container at least three times with sample water. A multiparameter field probe (Hydro Lab ${ }^{\mathrm{TM}}$ ) with a flowthrough cell was used in the field for measurements of $\mathrm{pH}$ and conductivity. After collection, all samples were labeled and placed in darkened coolers until the end of the day when they were sorted by sample type and preserved appropriately. Samples intended for total $\mathrm{Hg}$ and $\mathrm{MeHg}$ analysis were collected using trace-metal-clean techniques as outlined by Olson and DeWild (1999). Briefly, total Hg and $\mathrm{MeHg}$ samples were collected in 1-L Teflon bottles by qualified field personnel who wore copolymer vinyl gloves at all times during sampling to minimize artifact contamination. Teflon bottles are advantageous for several reasons: (1) they are nonbreakable; (2) they are resistive to chemical breakdown under the rigorous cleaning procedures employed by the USGS Mercury Research Lab (4 molar hydrogen chloride at $65^{\circ} \mathrm{C}$ for 24 hours); and (3) they minimize $\mathrm{Hg}$ and $\mathrm{MeHg}$ loss to container walls and greatly reduce gaseous $\mathrm{Hg}$ exchange into or out of the container. After cleaning, the Teflon bottles are partially filled with about $100 \mathrm{~mL}$ of 1 percent hydrogen chloride, and stored in two layers of zip-type plastic bags until use. Major cation and anion samples were collected in precleaned 250-mL plastic (polyethylene) bottles. Water samples for total organic carbon (TOC) determinations were collected in 40-mL glass vials with septum-piercing lids.

Sample preservation and shipping procedures were as follows: total $\mathrm{Hg}$ and $\mathrm{MeHg}$ samples were preserved by adding concentrated, low-Hg hydrochloric acid to 1 percent by volume (for example, $10 \mathrm{~mL}$ of concentrated hydrogen chloride was added to a 1-L sample), and then hermetically sealed in two layers of zip-type bags. Major cation samples were preserved with $2 \mathrm{~mL}$ of concentrated, high-purity nitric acid, whereas major anion and organic carbon samples were preserved in dark, $\operatorname{cool}\left(4^{\circ} \mathrm{C}\right)$ ice chests. All samples were shipped overnight to the USGS Mercury Research Lab in Middleton, Wisconsin, for processing and analysis.
A brief description of the analytical procedures for total $\mathrm{Hg}$ and $\mathrm{MeHg}$ in water is given here, but a complete description can be found in Olson and DeWild (1999), DeWild and others (2004), and Olund and others (2004). Total $\mathrm{Hg}$ and $\mathrm{MeHg}$ determinations were performed at the USGS Mercury Research Lab, a facility specifically designed for and dedicated to low-level speciation analysis of environmental samples. Total $\mathrm{Hg}$ was determined by cold vapor atomic fluorescence spectroscopy (CVAFS), following oxidation with bromine monochloride at $50^{\circ} \mathrm{C}$, reduction by stannous chloride $\left(\mathrm{SnCl}_{2}\right)$, and purge-and-trap of the evolved gaseous $\mathrm{Hg}$ onto gold-coated, glass-bead columns. The analytical procedure for $\mathrm{MeHg}$ is a two-step process involving distillation of the sample to separate the $\mathrm{MeHg}$ from potential matrix interference effects of organic carbon, followed by aqueous phase ethylation and quantification using gas chromatography and CVAFS. Analyses for the isotope tracers utilized in the experimental part of this study were analytically determined using the same procedures, with the exception that CVAFS was not used for detection and quantification. For these samples, the experimentally added isotope tracers, ${ }^{201} \mathrm{Hg}$ and $\mathrm{Me}^{199}$, were quantified using a PerkinElmer Elan 6100, inductively coupled plasma mass spectrometer, also located at the USGS Mercury Research Lab. Analysis of TOC was performed using a Shimadzu (model TOC-V CSH) analyzer that utilizes a high temperature $\left(680^{\circ} \mathrm{C}\right)$ combustion and catalytic oxidation method, followed by detection and quantification using infrared adsorption.

Major ion analyses were conducted at the Wisconsin State Laboratory of Hygiene in Madison, Wisconsin. Cations were measured using inductively coupled plasma mass spectrometry, with the exception of calcium and sodium, which were determined by inductively coupled plasma-atomic absorption spectrometry. Major anions (chloride and sulfate) were analyzed by liquid ion chromatography, and alkalinity was tested by standard potentiometric titration (American Public Health Association and others, 2005).

\section{Laboratory Experiments}

The objective of this part of the study was to simulate, under controlled but varying laboratory conditions, possible changes to total $\mathrm{Hg}$ and $\mathrm{MeHg}$ concentrations in the Upper Floridan aquifer during operation of the CERP ASR project. In particular, laboratory studies were conducted to assess whether processes that affect $\mathrm{Hg}$ concentrationsspeciation and transport (methylation, demethylation, sorp- 
tion and desorption-might occur during storage periods, and to assist in the interpretation of field data.

The experimental setup (fig. 2) involved a series of nine 2-L incubation bottles containing filtered water from the rim canal on the east side of Lake Okeechobee, pulverized rock material from the Upper Floridan aquifer, and a sparging gas (air or nitrogen) to control the redox condition inside the bottles. Water from the rim canal was chosen because it is one of the likely water sources for the ASR project. The South Florida Water Management District provided the rock material that was derived from a semicontinuous core drilled for a CERP ASR pilot project well southwest of Lake Okeechobee. The 12 specific core segments (about 2 in. wide by about $3 \mathrm{ft}$ long) were from two depth intervals: 830-840 ft and 1,020-1,030 ft below land surface. Each core segment was crushed into irregular pieces with an average diameter of about 0.2 in., using a pre-cleaned stainless steel mallet and plate. All of the crushed rock was combined into a large plastic bin, homogenized, and then distributed into the incubation bottles. The bottles were made of polyethylene terephthalate $\mathrm{G}$ copolymer (PETG), because it has very low gas permeability, low sorption potential for $\mathrm{Hg}$ and $\mathrm{MeHg}$, and it is opaque to ultraviolet light, which can cause photochemical changes to $\mathrm{Hg}$ speciation. Teflon tubing was used to connect 2-L PETG bottles to gas flowmeters and then to the sparging gas. Tight-fitting $1 / 4$-in. holes were drilled into the lids of the PETG bottles so that $1 / 4-i n$. Teflon tubing (all tubing diameters listed are outside diameters) could be inserted into the bottles. Flowmeters were placed in line for each bottle to maintain a regular and equal flow rate (0.3 L per minute) for each experimental test. Each sparging line had an in-line gold trap to eliminate possible $\mathrm{Hg}$ contamination associated with the sparging gas.

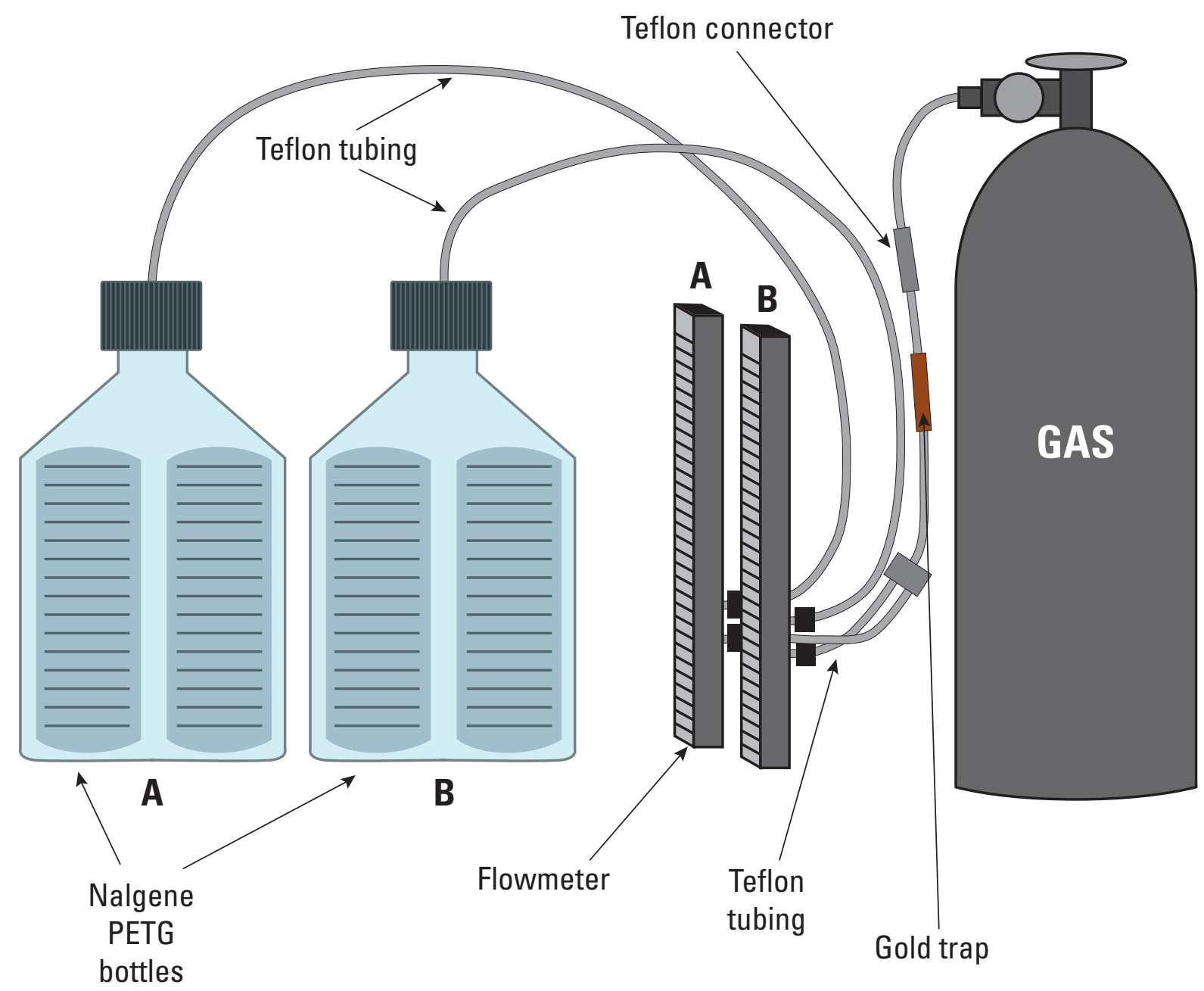

Figure 2. Laboratory incubation experiment apparatus. Although nine 2-liter bottles were used for the experiment, two bottles are illustrated here. 
Each PETG bottle, except for the controls (described below), initially received about $500 \mathrm{~mL}$ by volume of the crushed aquifer rock. Each bottle then was filled with 1.5 L of the filtered canal water. The canal water had been spiked with about $3.3 \mathrm{ng} / \mathrm{L}$ of the isotope tracers $\mathrm{Me}^{199} \mathrm{Hg}$ and ${ }^{201} \mathrm{Hg} 5$ days before the start of the experiment to allow for equilibration of the isotopes with the water matrix. The starting concentrations were chosen to approximate the levels (low nanograms per liter) of ambient $\mathrm{Hg}$ and $\mathrm{MeHg}$ in the native canal water utilized in the experiment. The starting concentration of $\mathrm{Me}^{201} \mathrm{Hg}$ is greater than the typically observed MeHg levels in Everglades surface water (about 0.5 to $1 \mathrm{ng} / \mathrm{L}$ ). To reliably detect the tracer during the experiment, however, a starting concentration of about $3 \mathrm{ng} / \mathrm{L}$ was deemed necessary. The purpose of the spikes was twofold: (1) to allow for distinguishing $\mathrm{Hg}$ species that are from the water phase from those that may be derived from sorption or desorption from the rock, and (2) to allow for direct examination of methylation and demethylation potential under varying redox conditions.

In all, five anaerobic and four aerobic experiments were conducted. The five anaerobic experiments included the following: crushed rock and canal water; a replicate crushed rock and canal-water test; sterilized rock (heated to $125^{\circ} \mathrm{C}$ for 24 hours) and canal water; surface water only (control); and, crushed rock and deionized water. The four aerobic experiments included the following: crushed rock and canal water; a replicate crushed rock and canal-water test; and surface water only (control). Sampling was conducted at six specific times: 0, 2, 4, 8, 12, and 16 weeks, beginning in February 2004. For each sampling, about $200 \mathrm{~mL}$ of water was slowly pumped into a pre-cleaned Teflon bottle using a peristaltic pump and a pre-cleaned Teflon line. Samples for TOC and sulfate analyses also were collected, but due to volume limitations these samples were only collected during the first and last sampling period. $\mathrm{Hg}$ samples were immediately preserved with $2 \mathrm{~mL}$ of concentrated low-mercury hydrogen chloride, and the TOC/sulfate samples were kept refrigerated until analysis. For each of the TOC samples acquired from the experiments, the specific ultraviolet absorbance (SUVA) also was measured. SUVA is a qualitative measure for the overall composition of TOC in a water sample (Haitzer and others, 2002) and was determined by measuring adsorption at 254 nanometers and normalizing these measurements to the concentration of TOC in the sample. High SUVA values indicate a TOC matrix with more aromatic components (for example, humic acids), whereas low SUVA values indicate a more aliphatic composition of the TOC matrix. A basic understanding of the nature of TOC character is important for evaluating the degree of interaction between organic carbon and $\mathrm{Hg}$.

\section{Evaluation of Field Sample Results}

Overall, concentrations of total $\mathrm{Hg}$ and $\mathrm{MeHg}$ in both the Upper Floridan aquifer and surficial aquifers are very low, with mean concentrations of about $0.41 \mathrm{ng} / \mathrm{L}$ and less than $0.07 \mathrm{ng} / \mathrm{L}$, respectively (fig. 3; table 2). Low $\mathrm{MeHg}$ concentrations were somewhat surprising, given that sulfate reduction was strongly indicated by the ubiquitous presence of hydrogen sulfide odor from samples taken from the surficial aquifers and the Upper Floridan aquifer. In addition, observed $\mathrm{MeHg}$ levels showed very little spatial variability (horizontally and vertically) in either the Floridan or surficial aquifers (minimum and maximum values observed were 0.055 and $0.081 \mathrm{ng} / \mathrm{L}$, respectively). Total $\mathrm{Hg}$ concentrations were more variable (minimum and maximum values observed were 0.10 and $4.14 \mathrm{ng} / \mathrm{L}$, respectively), and the mean concentration for the Floridan was about one-third that of samples derived from the surficial aquifers ( 0.16 and $0.50 \mathrm{ng} / \mathrm{L}$, respectively). This difference is likely due to the surficial aquifer samples having five times greater concentrations of TOC than the deeper Floridan, and the stabilizing effect of natural organic matter on $\mathrm{Hg}$ in water (Haitzer and others, 2002). Although $\mathrm{MeHg}$ concentrations in the Floridan and surficial aquifers are very low, the ratios of total $\mathrm{Hg}$ to $\mathrm{MeHg}$ are high, with an average ratio of 0.41 and a maximum observed ratio of 0.91 , which are high compared to the published literature (Wiener and others, 2003). A high total $\mathrm{Hg}$ to $\mathrm{MeHg}$ ratio is generally an indicator of greater methylation potential in surface water and sediments. The use of this indicator, however, is dubious at the very low total $\mathrm{Hg}$ and $\mathrm{MeHg}$ concentrations observed in this study. It is important to note that the total $\mathrm{Hg}$ and $\mathrm{MeHg}$ concentrations in ground water are substantially less than the concentrations that are generally observed in surface water in south Florida (about 2-4 ng/L, and 0.1-0.2 ng/L, respectively). Thus, from the perspective of direct loading of $\mathrm{Hg}$ and $\mathrm{MeHg}$ to local wetlands, the discharge of recovered ASR waters from the Floridan and surficial aquifers is of little concern.

Chemical results from samples collected from the Upper Floridan aquifer show significantly higher conductivity, sodium, chloride, and sulfate concentrations compared to the samples from the surficial aquifers (table 3). Greater sodium, sulfate, and chloride ion concentrations at depth are likely due to prolonged contact time for dissolution of aquifer minerals and mixing with relic 
seawater (Reese, 2004). Of these constituents, sulfate is the primary concern with regard to $\mathrm{MeHg}$ production, because results show that ground water in the Floridan is about five times greater in sulfate concentration than water collected from the surficial aquifers (214 and $43 \mathrm{mg} / \mathrm{L}$, respectively). On the other hand, samples from the surficial aquifers are about five times greater in organic carbon concentration compared to samples from the Floridan $(9.9$ and $1.8 \mathrm{mg} / \mathrm{L}$, respectively). The organic carbon concentrations in water from the surficial aquifers are similar to what is observed in surface water (wetlands, lakes, and streams) in south Florida. Injection of shallow ground water and (or) surface water will likely increase the organic carbon concentrations of the Floridan near the site of injection compared to ambient levels. Thus, recovered water from a functioning ASR program in south Florida could contain TOC and sulfate concentrations that could subsequently stimulate $\mathrm{MeHg}$ production if released to the local environments, including the Everglades.

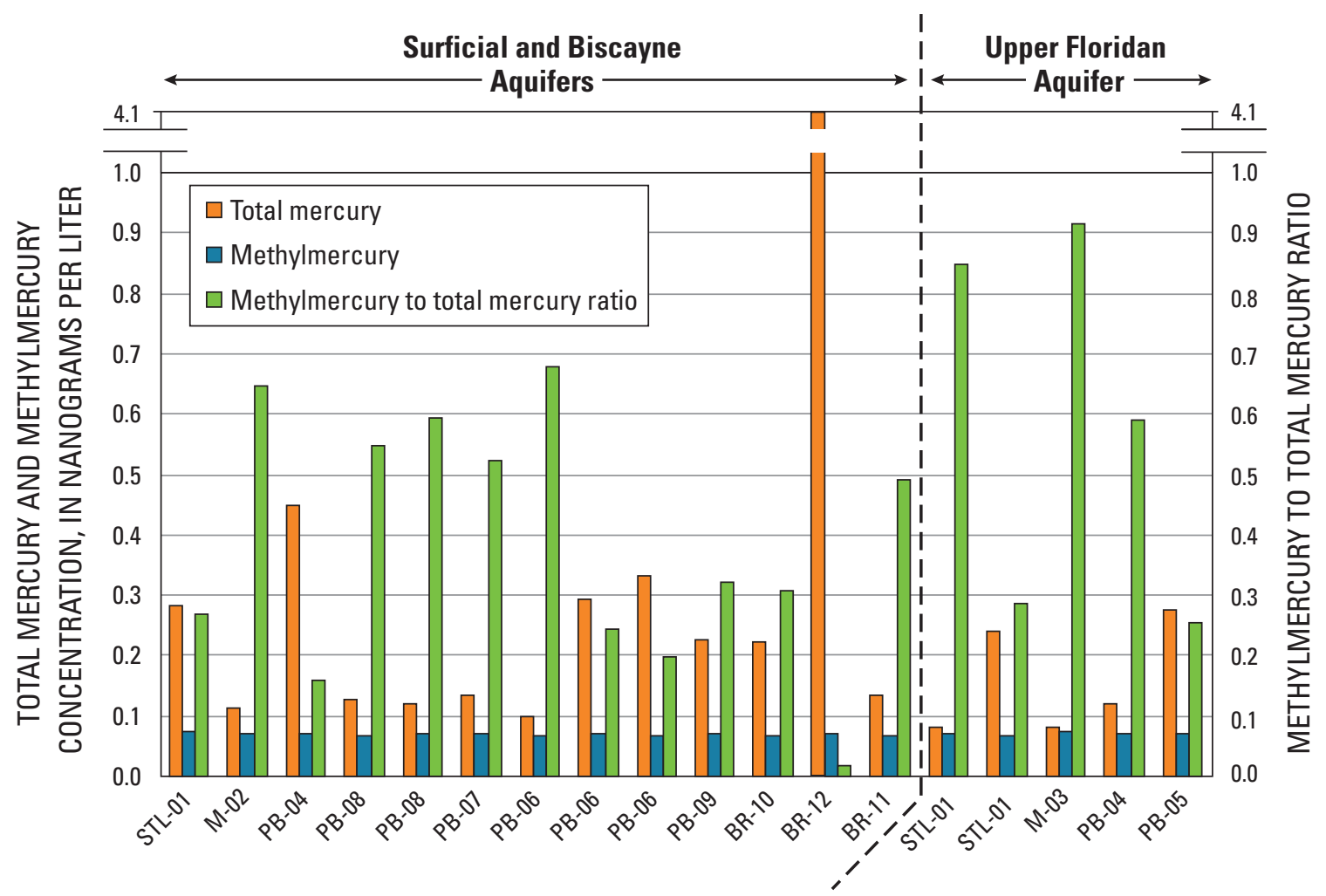

SAMPLE SITES (NORTH TO SOUTH)

Figure 3. Total mercury and methylmercury concentrations for the municipal water-supply wells sampled for this study. Data are arranged from north (left) to south (right) along the bottom axis. 
Evaluation of Experimental Samples Results

The last two goals of the project focused on assessing whether key chemical processes could occur during ASR storage periods. Results from the incubation experiments provided clear answers to these questions (figs. 4-7; table 4). First, rapid and substantial losses of total $\mathrm{Hg}$ and $\mathrm{MeHg}$ were observed in all incubation bottles containing the crushed aquifer rock. The inorganic isotopic tracers

${ }^{201} \mathrm{Hg}$ and $\mathrm{Me}^{199} \mathrm{Hg}$ mimicked the behavior of their natural analogs, generally showing an even greater loss rate from solution. It is important to note that the concentrations of both natural and isotopic $\mathrm{Hg}$ species in these experiments showed rapid declines, and were similar in concentration at the end of the 16 weeks. This strong corroboration supports the conclusions from these experiments and enables an understanding of the controlling factors of low total $\mathrm{Hg}$ and $\mathrm{MeHg}$ in ground water from the study area. No apparent gains in total $\mathrm{Hg}$ or $\mathrm{MeHg}$ in any of the experiments suggests that desorption (leaching from the Upper Floridan aquifer material) is not an important process.

Table 2. Results of specific chemical analyses from municipal wells.

[ID, identification number; $\mu$ Mhos/cm, microMohs per centimeter; mg/L, milligram per liter; ng/L, nanogram per liter; ND, no data, sample not collected; $\mathrm{HgT}$, total mercury; $\mathrm{MeHg}$, methylmercury; $\mathrm{MeHg} / \mathrm{HgT}$ ratio, ratio of methylmercury to total mercury; TOC, total organic carbon]

\begin{tabular}{|c|c|c|c|c|c|c|c|c|c|}
\hline Water utility name & Aquifer & $\begin{array}{c}\text { Utility } \\
\text { well ID }\end{array}$ & pH & $\begin{array}{l}\text { Conductivity } \\
\text { ( } \mu \text { Mhos/cm) }\end{array}$ & $\begin{array}{c}\text { Alkalinity } \\
\text { (mg/L) }\end{array}$ & $\begin{array}{c}\mathrm{HgT} \\
\text { (ng/L) }\end{array}$ & $\begin{array}{l}\text { MeHg } \\
\text { (ng/L) }\end{array}$ & $\begin{array}{c}\text { MeHg/ } \\
\text { HgT ratio }\end{array}$ & $\begin{array}{c}\mathrm{TOC} \\
\text { (mg/L) }\end{array}$ \\
\hline City of N. Lauderdale & Biscayne & 2 & 7.6 & 651 & 230 & 4.14 & 0.07 & 0.02 & 11.66 \\
\hline City of Deerfield Bch & Biscayne & 19 & 7.55 & 512 & 197 & .22 & .068 & .31 & 8.83 \\
\hline Tamarac & Surficial & 1 & 7.67 & 525 & 194 & .14 & .066 & .49 & 7.43 \\
\hline City of Ft. Lauderdale & Biscayne & 37 & 7.72 & 633 & 218 & .46 & .055 & .12 & 12.08 \\
\hline City of Lauderhill & Surficial & 5 & 7.62 & 485 & 190 & ND & ND & ND & ND \\
\hline Village of Tequesta & Floridan & 2 & 7.73 & 8020 & 149 & .12 & .072 & .59 & 1.37 \\
\hline Village of Tequesta & Surficial & 19 & 7.74 & 599 & 218 & .45 & .07 & .16 & 6.02 \\
\hline City of Boca Raton & Biscayne & BR1 & 7.45 & 570 & 208 & .23 & .072 & .32 & 12.35 \\
\hline Village of Palm Springs & Surficial & 17 & 7.41 & 595 & 240 & .13 & .07 & .52 & 11.37 \\
\hline Village of Palm Springs & Surficial & 12 & 7.34 & 737 & 268 & ND & ND & ND & ND \\
\hline Village of Wellington & Surficial & 24 & 7.36 & 799 & 268 & .13 & .069 & .55 & 13.76 \\
\hline Village of Wellington & Surficial & 22 & 7.3 & 754 & 268 & ND & ND & ND & ND \\
\hline Village of Wellington & Surficial & 19 & 7.4 & 737 & 253 & .128 & .071 & .6 & 11.03 \\
\hline West Palm Beach & Surficial & 2 & 7.36 & 599 & 218 & .298 & .081 & .28 & 6.88 \\
\hline West Palm Beach & Floridan & ASR & 7.71 & 6570 & 133 & .28 & .07 & .25 & 1.27 \\
\hline Boynton Beach & Biscayne & $7 \mathrm{~W}$ & 7.27 & 607 & 251 & .29 & .071 & .24 & 14.24 \\
\hline Boynton Beach & Biscayne & $15 \mathrm{E}$ & 7.47 & 528 & 199 & .33 & .066 & .2 & 10.9 \\
\hline Boynton Beach & Biscayne & $6 \mathrm{E}$ & 7.68 & 481 & 154 & .1 & .067 & .68 & 2.37 \\
\hline City of Stuart & Surficial & 3 & 7.68 & 545 & 236 & .11 & .072 & .65 & 5.51 \\
\hline Sailfish Point & Floridan & 2 & 7.84 & 4600 & 153 & .08 & .073 & .91 & 1.97 \\
\hline Fort Pierce & Floridan & F-8 & 7.92 & 1510 & 147 & .08 & .07 & .85 & 2.07 \\
\hline Fort Pierce & Floridan & F-4 & 7.9 & 1550 & 167 & .24 & .069 & .29 & 2.56 \\
\hline Fort Pierce & Surficial & 7 & 7.92 & 756 & 183 & ND & ND & ND & ND \\
\hline Fort Pierce & Surficial & $16 \mathrm{~S}$ & 7.59 & 646 & 256 & .28 & .076 & .27 & 13.21 \\
\hline
\end{tabular}


Rapid loss of $\mathrm{Hg}$ species was observed in all the experiments (aerobic and anaerobic) using crushed rock (figs. 4 and 5), whereas slow and incomplete loss was observed in the control bottles (those with no crushed rock, fig. 6). This indicates that $\mathrm{Hg}$ and $\mathrm{MeHg}$ are removed from aqueous solution by net sorption to mineral surfaces. Although this does not mean that some desorption is not occurring also, the uniform response of all the experiments strongly supports the conclusion that, overall, net sorption dominates the exchange process between $\mathrm{Hg}$, $\mathrm{MeHg}$, and the aquifer rock. Because the experimental design employed crushed aquifer rock that presumably has a greater rock-surface area to water ratio, the experimentally observed loss rates of dissolved $\mathrm{Hg}$ and $\mathrm{MeHg}$ may be greater than what might be observed under operating ASR conditions and an intact aquifer substrate. However, the overall agreement between $\mathrm{Hg}$ and $\mathrm{MeHg}$ concentrations in ground-water samples from the surficial aquifers and the Floridan, and those observed from the experiments indicates that these loss rates may be good proxies for loss rates under ASR conditions. Finally, because the mass $\mathrm{Hg}$ in ground water or injected surface water is probably so small (nanograms per liter of water) and the mass of rock is about 12 orders of magnitude greater (about $2 \mathrm{~kg}$ per

Table 3. Results of specific chemical analyses of major cations and anions from municipal wells.

[ID, identification number; $\mathrm{mg} / \mathrm{L}$, milligram per liter; ND, no data]

\begin{tabular}{|c|c|c|c|c|c|c|c|c|}
\hline Water utility name & Aquifer & $\begin{array}{c}\text { Utility } \\
\text { well ID }\end{array}$ & $\begin{array}{c}\text { Calcium } \\
\text { (mg/L) }\end{array}$ & $\begin{array}{c}\text { Magnesium } \\
\text { (mg/L) }\end{array}$ & $\begin{array}{c}\text { Sodium } \\
\text { (mg/L) }\end{array}$ & $\begin{array}{c}\text { Potassium } \\
\text { (mg/L) }\end{array}$ & $\begin{array}{l}\text { Sulfate } \\
\text { (mg/L) }\end{array}$ & $\begin{array}{c}\text { Chloride } \\
\text { (mg/L) }\end{array}$ \\
\hline City of N. Lauderdale & Biscayne & 2 & 105 & 4.3 & 34.6 & 2 & 47.4 & 55.7 \\
\hline City of Deerfield Bch & Biscayne & 19 & 91.2 & 3.2 & 19.2 & 2 & 39.9 & 32.5 \\
\hline Tamarac & Surficial & 1 & 89.7 & 3.6 & 20.8 & 2 & 41.4 & 34.5 \\
\hline City of Ft. Lauderdale & Biscayne & 37 & 84.5 & 9.6 & 39.1 & 4 & 31.5 & 63.1 \\
\hline City of Lauderhill & Surficial & 5 & 87.5 & 2.4 & 18.3 & 1 & 33.2 & 30.5 \\
\hline Village of Tequesta & Floridan & 2 & 165 & 174 & 1,320 & 43 & 261.2 & 2,570 \\
\hline Village of Tequesta & Surficial & 19 & 73.4 & 1.7 & 17 & 2 & 27.7 & 29.1 \\
\hline City of Boca Raton & Biscayne & BR1 & 97 & 3.8 & 24.5 & 2 & 44.7 & 42.1 \\
\hline Village of Palm Springs & Surficial & 17 & 115 & 3.6 & 16.5 & 2 & 53.6 & 28.9 \\
\hline Village of Palm Springs & Surficial & 12 & 122 & 4.8 & 42.4 & ND & 45.3 & 72.3 \\
\hline Village of Wellington & Surficial & 24 & 124 & 5.9 & 46.4 & 4 & 62.4 & 75.3 \\
\hline Village of Wellington & Surficial & 22 & 125 & 5.8 & 34 & 3 & 62.1 & 57 \\
\hline Village of Wellington & Surficial & 19 & 119 & 5.2 & 32.9 & 5 & 51.7 & 61.6 \\
\hline West Palm Beach & Surficial & 2 & 93.4 & 3.2 & 30.6 & ND & 19 & 54.4 \\
\hline West Palm Beach & Floridan & ASR & 124 & 136 & 1,100 & 41 & 369.4 & 1,960 \\
\hline Boynton Beach & Biscayne & $7 \mathrm{~W}$ & 105 & 2.8 & 23.9 & ND & 19.2 & 39.9 \\
\hline Boynton Beach & Biscayne & $15 \mathrm{E}$ & 91.8 & 3.4 & 19.7 & 1 & 36 & 33.3 \\
\hline Boynton Beach & Biscayne & $6 \mathrm{E}$ & 86.6 & 2.2 & 16.4 & 3 & 62.7 & 29.5 \\
\hline City of Stuart & Surficial & 3 & 100 & 2.9 & 15.1 & 1 & 31.1 & 18.1 \\
\hline Sailfish Point & Floridan & 2 & 99.4 & 106 & 688 & 26 & 160.9 & 1,340 \\
\hline Fort Pierce & Floridan & F-8 & 56.4 & 46.2 & 179 & 10 & 119.9 & 324 \\
\hline Fort Pierce & Floridan & F-4 & 51.9 & 42 & 203 & 13 & 158.9 & 302 \\
\hline Fort Pierce & Surficial & 7 & 80.4 & 10.2 & 65.9 & 5 & 71.4 & 92.2 \\
\hline Fort Pierce & Surficial & $16 \mathrm{~S}$ & 112 & 4.7 & 25.6 & 2 & ND & 36.1 \\
\hline
\end{tabular}




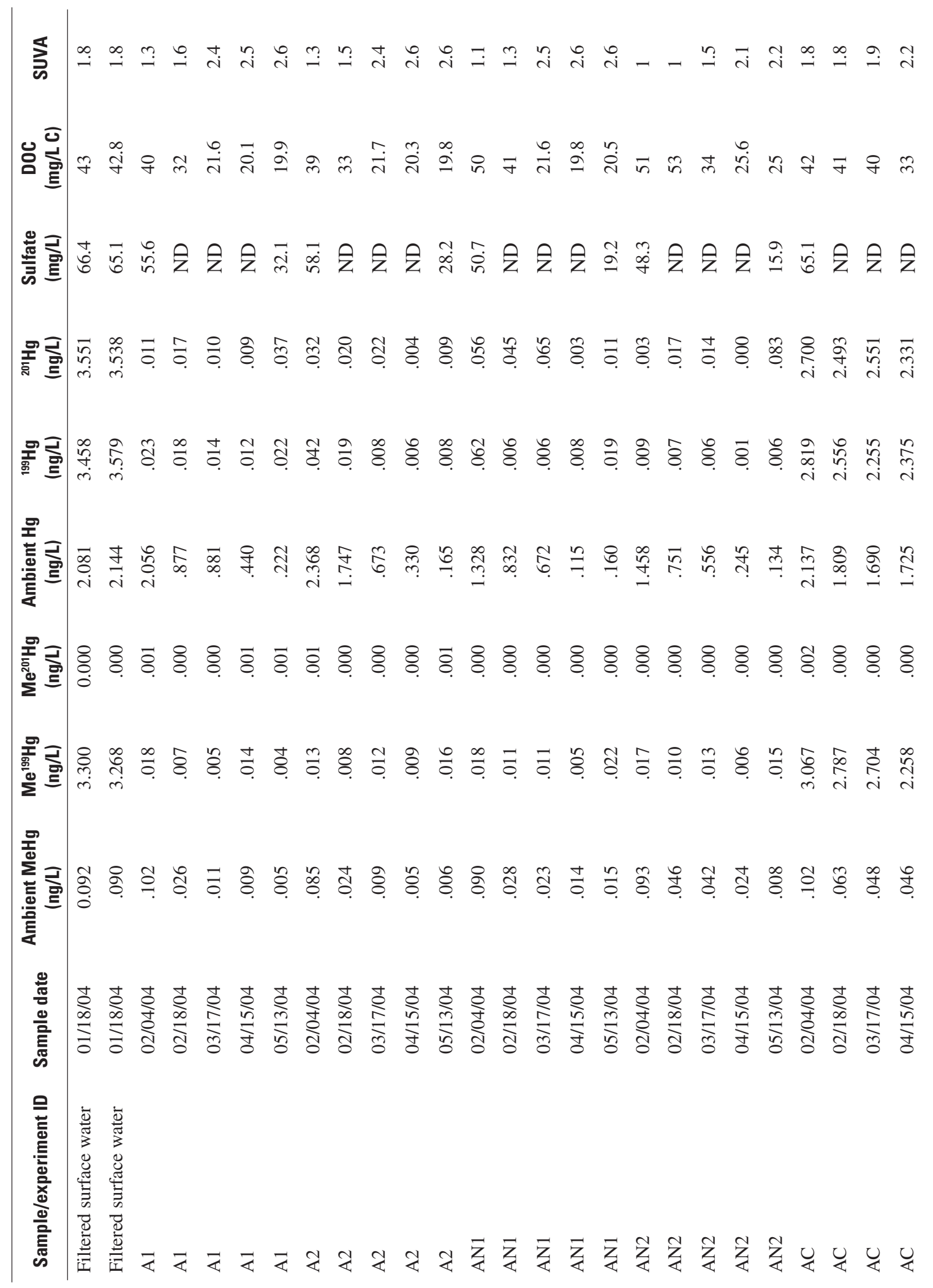




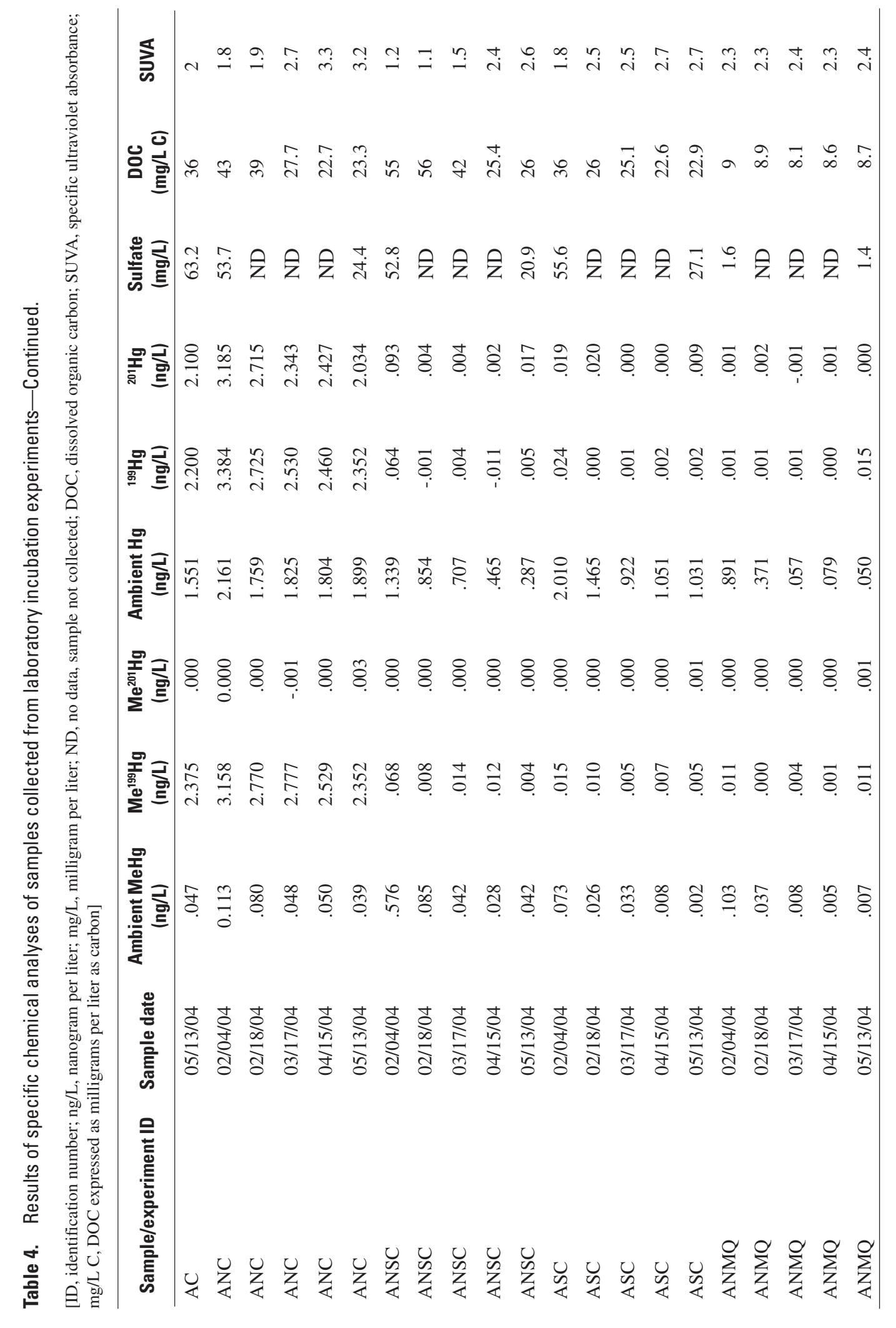


liter of rock), the aquifer itself could be an inexhaustible sink for $\mathrm{Hg}$ and $\mathrm{MeHg}$ from ground water.

The lack of any observed formation of $\mathrm{Me}^{201} \mathrm{Hg}$ (introduced as inorganic ${ }^{201} \mathrm{Hg}$ ) in the experimental results indicates that net $\mathrm{MeHg}$ production is minimal to nonexistent (table 4). Likewise, no detectable inorganic ${ }^{199} \mathrm{Hg}$ (introduced as $\mathrm{Me}^{199} \mathrm{Hg}$ ) in the analyzed samples indicates that net demethylation also is not active under anaerobic or aerobic conditions in contact with the crushed rock (table 4). It should be noted, however, that because greater than
99 percent of the starting mass of ${ }^{201} \mathrm{Hg}$ and $\mathrm{Me}^{199} \mathrm{Hg}$ was not in solution at the end of the experiment (presumably lost to sorption as noted above) it is possible that methylation and demethylation were occurring, but that the net products of these reactions were lost so rapidly to the rock surfaces that the byproducts could not be observed. Given the very small mass of isotope utilized in the experiments (about $5 \mathrm{ng}$ per bottle) and the large mass of rock (about $1 \mathrm{~kg}$ ), it was not possible to quantify the isotopic tracers at the conclusion of the experiment. The slow but compara-
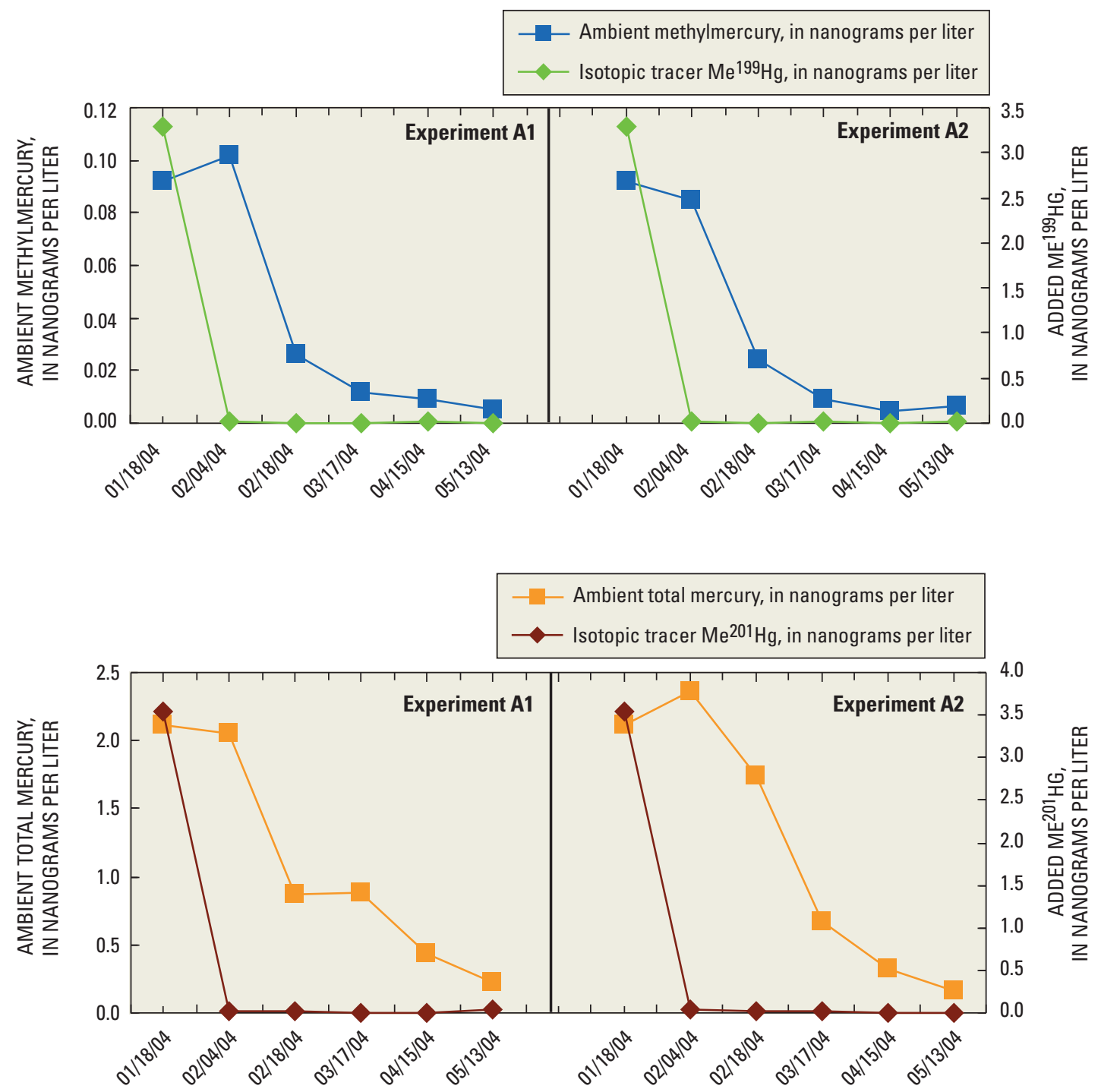

Figure 4. Results from experiments $A 1$ and $A 2$, replicate aerobic incubations containing surface water and crushed rock. Top panel shows the results for ambient methylmercury $\left(\mathrm{MeHg}\right.$ ) and the isotopic tracer $\mathrm{Me}^{199} \mathrm{Hg}$; bottom panel shows results for ambient total mercury $(\mathrm{Hg})$ and the isotopic tracer ${ }^{201} \mathrm{Hg}$. 
bly minimal loss of $\mathrm{Hg}$ and $\mathrm{MeHg}$ isotopes observed in the control bottles (those lacking crushed rock, fig. 6) is likely due to sorption to the walls of the bottle.

Sulfate reduction and organic carbon consumption were clearly observed in the incubation bottles under aerobic and anaerobic conditions (fig. 7; table 4). A concomitant increase in SUVA indicates the residual organic carbon pool in the bottles is evolving toward a more complex (aromatic) mixture, with the more aliphatic compounds preferentially utilized by the sulfate-reducing bacteria. The molar loss rate of carbon compared to sulfate is about $2: 1$, which is the theoretical value predicted if microbial sulfate reduction is the process leading to the dual consumption of sulfate and organic carbon (Stumm and Morgan, 1981). Sulfate reduction appears to have occurred in the experiment, without appreciable $\mathrm{MeHg}$ being observed, which strongly suggests that either loss by sorption to the rock virtually masked the formation of $\mathrm{Me}^{201} \mathrm{Hg}$, or that high sulfide concentrations (the byproduct of sulfate reduction) inhibited the formation of $\mathrm{MeHg}$
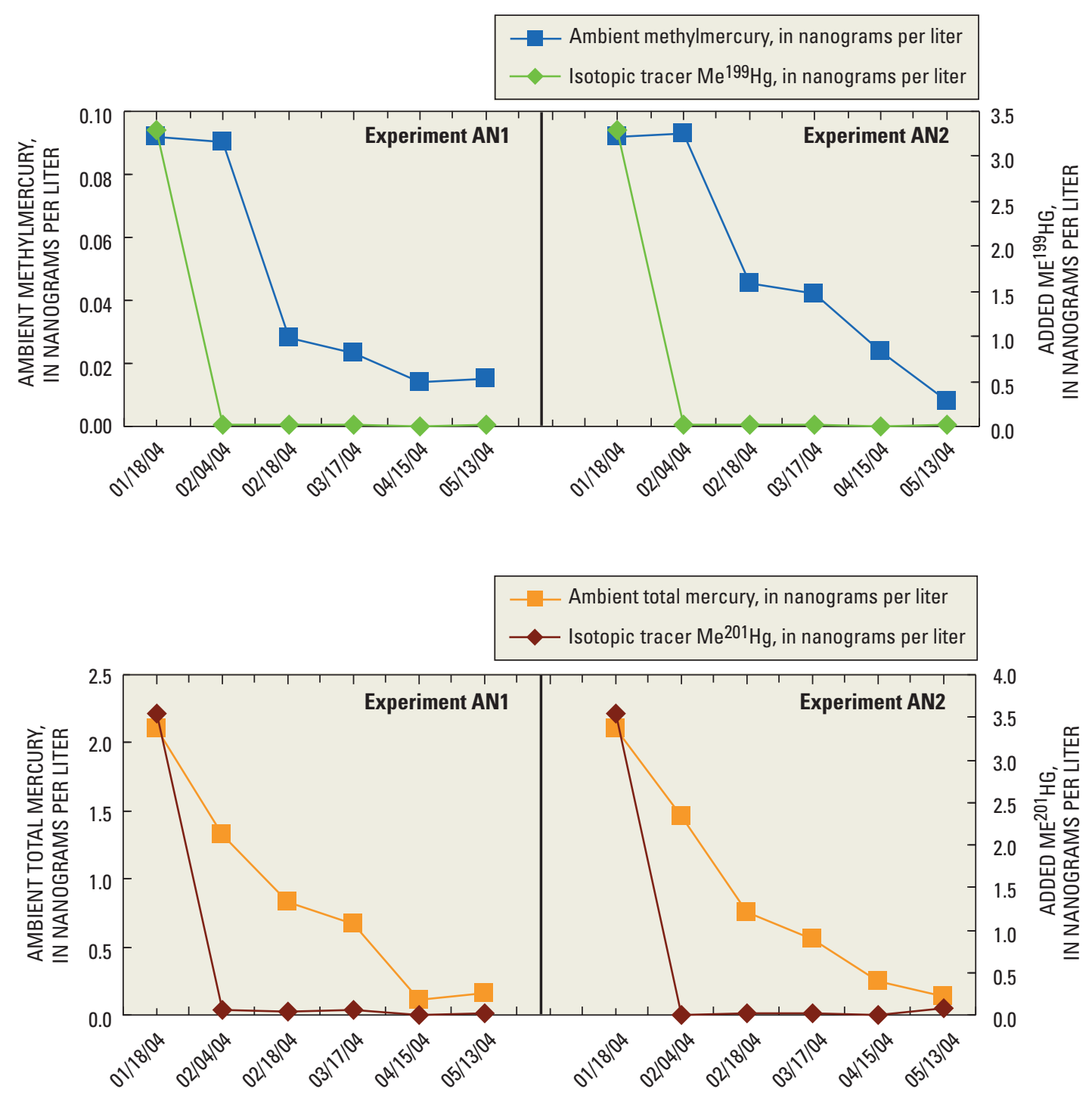

Figure 5. Results from experiments AN1 and AN2, replicate anaerobic incubations containing surface water and crushed rock. Top panel shows the results for ambient methylmercury $(\mathrm{MeHg})$ and the isotopic tracer $\mathrm{Me}^{199} \mathrm{Hg}$; bottom panel shows results for ambient total mercury $(\mathrm{Hg})$ and the isotopic tracer ${ }^{201} \mathrm{Hg}$. 
(Benoit and others, 1999). The fact that sulfate reduction appears to have occurred in the anaerobic control experiment, which did not contain the rock material, indicates that the sulfide inhibition process effect is the more likely explanation. Over the course of the 16-week experiment, sulfate and organic carbon concentrations appeared to stabilize at relatively elevated levels, but it was not possible to conclude if sulfate reduction had actually ceased or had simply reached a low, steady-state rate. The fact that ample sulfate and organic carbon remained in solution at the conclusion of the experiment indicates that the availability of labile carbon could have been limiting sulfate-reduction activity.
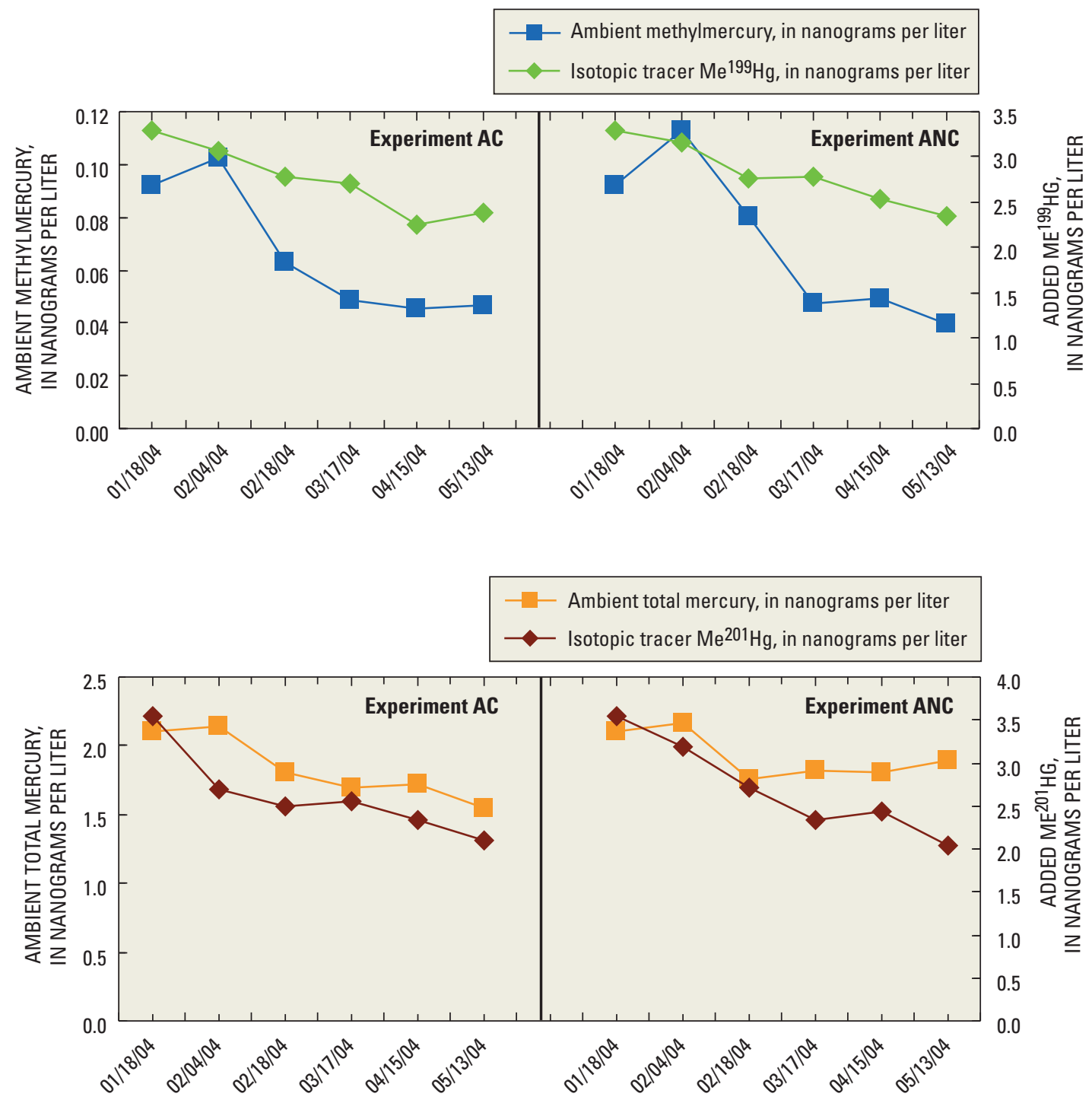

Figure 6. Results from experiments $A C$ and ANC, aerobic and anaerobic incubations, respectively, containing only filtered surface water. Top panel shows the results for ambient methylmercury ( $\mathrm{MeHg}$ ) and the isotopic tracer $\mathrm{Me}^{199} \mathrm{Hg}$; bottom panel shows results for ambient total mercury $(\mathrm{Hg})$ and the isotopic tracer ${ }^{201} \mathrm{Hg}$. 

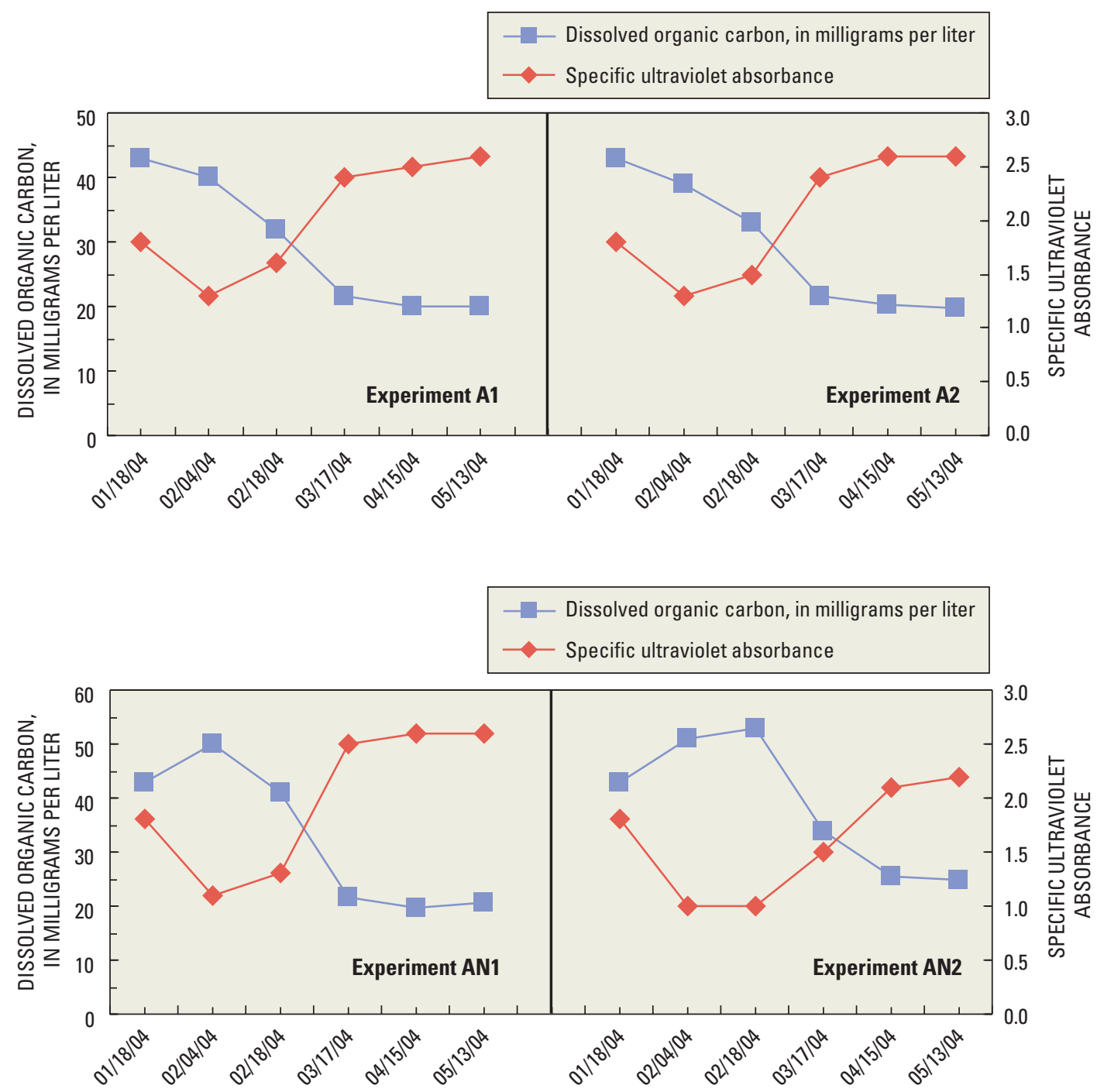

Figure 7. Dissolved organic carbon and specific ultraviolet absorbance (SUVA) results from the aerobic experiments A1 and A2 (top panel), and anaerobic experiments AN1 and AN2 (bottom panel), which both contain filtered surface water and crushed rock. 


\section{Summary and Conclusions}

The Everglades ecosystem restoration program is a complex and multifaceted effort that is challenging natural resource managers in south Florida to meet restoration program goals and to prepare for anticipated increases in water-supply needs. Planning and establishing a largescale ASR program is one way planners are attempting to improve water use and availability in the future. Although large-scale ecosystem restoration and ASR programs are being conducted elsewhere, the situation in south Florida is unique, because there are concerns that both might affect $\mathrm{Hg}$ contamination levels of aquatic food webs. In response to these concerns, the U.S. Geological Survey and U.S. Army Corps of Engineers collaborated on a study to evaluate how the proposed ASR program could affect $\mathrm{Hg}$ cycling and toxicity. The project had four overall goals that were addressed through a combined field and laboratory study approach. The four project goals were to: (1) determine background concentrations of $\mathrm{Hg}, \mathrm{MeHg}$, and other relevant ancillary chemical constituents in the surficial and Upper Floridan aquifers; (2) determine whether there are any spatial trends in $\mathrm{Hg}$ and $\mathrm{MeHg}$ concentrations in the aquifers; (3) determine whether net $\mathrm{MeHg}$ formation could occur during ASR storage periods; and (4) determine whether net changes in $\mathrm{Hg}, \mathrm{MeHg}$, sulfate, and organic carbon could occur during storage periods.

Overall, ground-water samples collected from water-utility wells that were screened in the target aquifers (surficial and Upper Floridan aquifers) for the ASR program revealed very low concentrations of $\mathrm{Hg}$ and $\mathrm{MeHg}$ concentrations (mean values of 0.41 and $0.07 \mathrm{ng} / \mathrm{L}$, respectively). There were no apparent spatial (horizontal or vertical) trends in the MeHg results; however, the total $\mathrm{Hg}$ concentrations in the surficial aquifers were about three times greater than the mean for the deeper Floridan ( 0.50 and $0.16 \mathrm{ng} / \mathrm{L}$, respectively). The greater total $\mathrm{Hg}$ concentrations probably were due to the stabilizing influence (reduced sorption loss) of TOC, which had concentrations about five times greater in samples taken from the surficial aquifers than the Floridan. Based on these results, it does not appear that recovered water from the ASR program would represent a significant additional direct load of $\mathrm{Hg}$ and $\mathrm{MeHg}$ to receiving waters in south Florida. Net production of $\mathrm{MeHg}$, however, can result from additions of sulfate and (or) natural organic carbon. The overall mean sulfate concentration observed in this study was $80 \mathrm{mg} / \mathrm{L}$, with much greater concentrations in samples from the Floridan $(214 \mathrm{mg} / \mathrm{L})$ than the surficial aquifers
(43 mg/L). The opposite trend was observed for TOC, where concentrations were about five times greater in the surficial aquifers compared to the Floridan (9.8 and $1.8 \mathrm{mg} / \mathrm{L}$, respectively). Given that the presumed CERP ASR program storage water (surface water near Lake Okeechobee) is elevated in organic carbon and sulfate, and much of the Upper Floridan aquifer is elevated in sulfate, at least some potential for increased MeHg production may arise from the release of recovered ASR water to wetland environments in south Florida.

Results from the laboratory incubation experiments support the conclusion that low concentrations of $\mathrm{Hg}$ and $\mathrm{MeHg}$ are due to losses from sorption to the aquifer rock. Rapid losses to sorption, which were observed for naturally occurring $\mathrm{Hg}$ and $\mathrm{MeHg}$, contained surface water used in the experiment as well as $\mathrm{Me}^{199} \mathrm{Hg}$ and the ${ }^{201} \mathrm{Hg}$ isotope tracers that were added at the beginning of the experiment. These results indicate that most of the $\mathrm{Hg}$ and $\mathrm{MeHg}$, which may be contained in injected surface water during ASR operation, will likely be present in the recovered water. The lack of any observed transformation of inorganic isotopes ${ }^{201} \mathrm{Hg}$ to $\mathrm{Me}^{201} \mathrm{Hg}$ or ${ }^{199} \mathrm{Hg}$ to $\mathrm{Me}{ }^{199} \mathrm{Hg}$ ) indicates that there is minimal potential for net methylation or demethylation under the conditions represented by the laboratory experiments. It is possible, however, that methylation and demethylation were occurring, but that the net products of these reactions were lost so rapidly to the rock surfaces that the byproducts could not be observed. Regardless, the results support the conclusion that net gains in MeHg during ASR storage are unlikely.

Sulfate reduction and organic carbon consumption were clearly observed during the incubation experiment. The observed carbon-to-sulfate molar loss rate of about 2:1 is the same as the predicted theoretical value if microbial sulfate reduction is the process leading to the dual consumption of sulfate and organic carbon. At the conclusion of the 16-week experiment, sulfate and organic carbon concentrations appeared to stabilize, but it was not possible to conclude if sulfate reduction had actually ceased or simply reached a low, steady-state rate. It is important to note that the apparent steady-state sulfate and organic carbon concentrations of about 20 to $30 \mathrm{mg} / \mathrm{L}$ at the end of the 16-week experiment are still elevated over what was observed in surface water from most unimpacted areas of the Everglades. Although organic carbon concentrations in the surface waters of the Everglades are not at concentrations considered limiting to microbial processes, sulfate is present at low concentrations (less than $1 \mathrm{mg} / \mathrm{L}$ ) in many pristine areas. In general, the concentration of sulfate observed in samples from Floridan and surficial aquifer 
wells (19 to $369 \mathrm{mg} / \mathrm{L}$ ) are substantially greater than most Everglades surface-water concentrations. Given the known links between sulfate loading and $\mathrm{MeHg}$ production, it is reasonable to conclude that sulfate added from the release of recovered ASR water could contribute to additional $\mathrm{MeHg}$ formation in receiving waters of the Everglades.

\section{Acknowledgments}

The authors are very grateful to Raycine M. Hodo from the University of Wisconsin for her significant help in many aspects of this project and the personal interest she took in executing critical aspects of the work. Mark Olson, John DeWild, and Shane Olund of the USGS Mercury Research Lab provided significant assistance to the experimental and laboratory analysis portions of this study. Mark Shafer from the U.S. Army Corps of Engineers and Robert Verrastro from the South Florida Water Management District provided valuable review comments for this report.

\section{References}

American Public Health Association and others, 2005, Standard methods for the examination of water and wastewater (21 ${ }^{\text {st }}$ ed.): Washington, D.C., 1368 p.

Bates A.L., Orem, W.H., Harvey, J.W. and Spiker, E.C., 2002, Tracing the sources of sulfur in the Florida Everglades: Journal of Environmental Quality, v. 31, p. 287-299.

Benoit, J.M., Gilmour, C.C., Mason, R.P., and Heyes, A., 1999, Sulfide controls on mercury speciation and bioavailability to methylating bacteria in sediment pore waters: Environmental Science Technology, v. 33, no. 6, p. 951-957.

Cleckner, L.B., Garrison, P.J., Hurley, J.P., Olson, M.L., and Krabbenhoft, D.P., 1998, Trophic transfer of methylmercury in the northern Everglades: Biogeochemistry, v. 40 , no. $2-3$, p. $347-361$.

Comprehensive Everglades Restoration Plan, 2002, U.S. Army Corps of Engineers and South Florida Water Management District: http://www.evergladesplan.org

DeWild, J.F., Olund, S.D., Olson, M.L., and Tate, M.T., 2004, Methods for the preparation and analysis of solids and suspended solids for methylmercury: U.S. Geological Survey Techniques and Methods Report, book 5, section A, chapter 7, $21 \mathrm{p}$.
Evers, D.C., Han, Y.J., Driscoll, C.T., and others, 2007, Biological mercury hotspots in the northeastern United States and southeastern Canada: Bioscience, v. 57, no. 1, p. 29-43.

Gilmour, C.C., Riedel, G.S., Ederlington, M.C., Bell, J.T., Benoit, J.M., Gill, G.A., and Stordal, M.C., 1998, Methylmercury concentrations and production rates across a trophic gradient in the Northern Everglades: Biogeochemistry, v. 40, p. 326-346.

Haitzer, M., Aiken, G.R., and Ryan, J.N., 2002, Binding of mercury (II) to dissolved organic matter: The role of the mercury-to-DOM concentration ratio: Environmental Science Technology, v. 36, no. 16, p. 3564-3570.

Hurley, J.P., Krabbenhoft, D.P., Cleckner, L.B, Olson, M.L., Aiken, G.R., and Rawlik , P.J., 1998, System controls on aqueous mercury distribution in the northern Everglades: Biogeochemistry, 40, p. 293-310.

Jeremiason, J.D., Engstrom, D., Swain, E.B., and others, 2006, Sulfate addition increases methylmercury production in an experimental wetland: Environmental Science Technology, 40, no. 12 , p. 3800-3806.

Krabbenhoft, D.P., 1996, Mercury studies in the Florida Everglades: U.S. Geological Survey Fact Sheet, 166-96, 4 p.

Krabbenhoft, J.P., Hurley, M.L., Olson, M.L., and Cleckner, L.B., 1998, Diurnal variability of mercury phase and species distributions in the Florida Everglades: Biogeochemistry, 40, p. 311-325.

Miller, J.A., 1990, Ground water atlas of the United States: Segment 6, Alabama, Florida, Georgia, and South Carolina: U.S. Geological Survey Hydrologic Atlas 730-G, 28 pages.

National Research Council of the National Academies, 2002, Regional issues in aquifer storage and recovery for Everglades restoration: A review of the ASR Regional Study Project Management Plan of the Comprehensive Everglades Restoration Plan: Committee on Restoration of the Greater Everglades Ecosystem Water Science and Technology Board, Board on Environmental Studies and Toxicology, Division on Earth and Life Studies: Washington, D.C., National Academies Press, 75 pages.

Olson, M.L., and DeWild, J.F., 1999, Techniques for the collection and species-Specific analysis of low levels of mercury in water, sediment, and biota: U.S. Geological Survey Water-Resources Investigations Report 99-4018-B, 11 p. 
Olund, S.D., DeWild, J.F., Olson, M.L. and Tate, M.T., 2004, Methods for the preparation and analysis of solids and suspended solids for total mercury: U.S. Geological Survey Techniques and Methods Report, book 5, section A, chapter 8, 23 p.

Orihel, D.M., Paterson, M.J., Gilmour, C.C., and others, 2006, Effect of loading rate on the fate of mercury in littoral mesocosms, Environmental Science and Technology, v. 40, no. 19 , p. 5992-6000.

Pyne, R.D.G., 1995, Groundwater recharge and wells: A guide to aquifer storage recovery: Boca Raton, Fla., Lewis Publishers/CRC Press, 376 p.

Ravichandran, M., Aiken, G.R., Reddy, M.M., and Ryan, J.N., 1998, Enhanced dissolution of cinnabar (mercuric sulfide) by organic matter from the Florida Everglades: Environmental Science and Technology, v. 32, no. 21, p. 3305-3311.

Reese, R.S., 2002, Inventory and review of aquifer storage and recovery in southern Florida: U.S. Geological Survey Water-Resources Investigations Report 02-4036, $56 \mathrm{p}$.
Reese, R.S., 2004, Hydrogeology, water quality, and distribution and sources of salintity in the Floridan aquifer system, Martin and St. Lucie Counties, Florida. U.S. Geological Survey Water-Resources Investigations Report 03-4242, 105 p.

Reese, R.S., and Memberg, S.J., 2000, Hydrogeology and the distribution of salinity in the Floridan aquifer system, Palm Beach County, Florida: U.S. Geological Survey Water-Resources Investigations Report 99-4061, $59 \mathrm{p}$.

Stumm, W., and Morgan, J.J., 1981, Aquatic chemistry: New York, John Wiley, Wiley Interscience Publication, $790 \mathrm{p}$.

Wanless, H.R., 2004, Keep it clean and do the research: Ground Water: v. 42, no. 2. p. 157.

Wiener, J.G., Krabbenhoft, D.P., Heinz, G.H., and Scheuhammer, A.M., 2003, Ecotoxicology of mercury, in Hoffman, D. J., Rattner, B.A., and others (eds.), Handbook of ecotoxicology ( $2^{\mathrm{d}}$ ed.), Boca Raton, Fla., CRC Press, chap. 16, p. 407-461.

\author{
Prepared by the Wisconsin Water Science Center: \\ U.S. Geological Survey \\ Wisconsin Water Science Center \\ 8505 Research Way \\ Middleton, WI 53562 \\ tel: (608) 828-9901 \\ fax: (608) 821-3817
}

This publication is available online at URL: http://pubs.usgs.gov/sir/2007/5240/

Information regarding the Wisconsin Water Science Center is available at URL:

http://wi.water.usgs.gov 
